\title{
External Ophthalmomyiasis Seen in a Patient From İstanbul, Turkey
}

\section{İstanbul' da Bir Hastada Gözlenen Oftalmomiyazis Eksterna Vakası}

\author{
Aylin Ardagil Akçakaya1, Fatma Sargın², Zeki Ilke Aslan³, Neslihan Sevimli', Fariz Sadigov ${ }^{4}$ \\ 1'Department of Ophthalmology, Medeniyet University Göztepe Training and Research Hospital, İstanbul, Turkey \\ ${ }^{2}$ Department of Infectious Diseases, İstanbul Medeniyet University, Göztepe Training and Research Hospital, İstanbul, Turkey \\ ${ }^{3}$ Department of Ophthalmology, Edremit State Hospital, Balıkesir, Turkey \\ ${ }^{4}$ Department of Ophthalmology, Medistyle Hospital, Baku, Azerbaijan
}

\section{ABSTRACT}

Ophthalmomyiasis externa, results from infestation of the conjunctiva by the larval form of Oestrus ovis. It is usually seen in rural areas. We report a case with ophthalmomyiasis externa in a young man living in an urban area (Istanbul, Turkey) who had no known history of traveling to the rural area. Even in patients living in urban areas ophthalmomyiasis externa should be taken into consideration in differential diagnosis of red eye. (Turkiye Parazitol Derg 2014; 38: 205-7)

Key Words: Ophthalmomyiasis externa, Oestrus ovis, urban area

Received: 08.02.2014

Accepted: 31.03.2014

\section{ÖZET}

Eksternal oftalmomiyazis, Oestrus ovis larvalarının konjonktivadaki enfestasyonları sonucu ortaya çıkar. Genellikle kırsal kesimde görülür. Bu vaka sunumunda kentsel yerleşim yerinde (İstanbul, Türkiye) oftalmomiyazis eksterna ile başvuran ve bilinen kırsal bölgeye yoluluk hikayesi olmayan genç bir erkek hastayı sunuyoruz. Kentsel yerleşim birimlerinde yaşıyor olsa dahi kırmızı gözle başvuran hastalarda eksternal oftalmomiyazis ayırıcı tanıda düşünülmelidir. (Turkiye Parazitol Derg 2014; 38: 205-7)

Anahtar Sözcükler: Eksternal oftalmomiyazis, Oestrus ovis, kentsel bölge

Geliş Tarihi: 08.02.2014

Kabul Tarihi: 31.03.2014

\section{INTRODUCTION}

Myiasis is a parasitic disease caused by the larvae of numerous dipteran fly species, including the sheep botfly Oestrus ovis. This species is an obligate parasite in the nasal cavities and frontal sinuses of sheep but may also cause infestation in humans. The primary site of infestation is usually the nose, ears, eyes, and skin but can also include the pharynx and genitourinary tract (1). Involvement of the eye is termed ophthalmomyiasis. Ophthalmomyiasis may be classified according to its location as external, internal, or orbital (2). It is common in sheep-farming areas, especially in the Mediterranean countries, Southern Africa, and Central America. Although Oestrus ovis is common, only a few cases have been reported in Turkey (3).

Address for Correspondence / Yazışma Adresi: Dr. Aylin Ardagil Akçakaya, Department of Ophthalmology, Medeniyet University, Göztepe Training and Research Hospital, İstanbul, Turkey. Phone: +90 5064060307 E-mail: aardagil@gmail.com DOI:10.5152/tpd.2014.3512

(C) Copyright 2014 Turkish Society for Parasitology - Available online at www.tparazitolderg.org

OTelif hakkı 2014 Türkiye Parazitoloji Derneği - Makale metnine www.tparazitolderg.org web sayfasından ulaşılabilir. 
Ophthalmomyiasis usually occurs in rural areas, where people live in close contact with farm animals; however, a few cases are also reported from urban areas.

We report this case in order to inform ophthalmologists to take into consideration ophthalmomyiasis externa in the differential diagnosis of red eye in any part of Turkey.

\section{CASE REPORT}

A 17-year-old male, a student from Istanbul, with no past ophthalmic history, presented to Göztepe Research and Training Hospital with continuous pain, irritation, lacrimation, and moving foreign body sensation in his left eye. He reported that a few days before, a fly had landed on his left eye conjunctiva, and he moved it away by washing the area. He also mentioned that he started wearing contact lenses for the first time a week ago. He described the attributed foreign body sensation as an adaptation to the contact lenses, and therefore, he did not visit a doctor. In the following days, his symptoms started aggravating and were localized only to his left eye; so, he attended our clinic 3 days after his contact with the fly.

The patient had removed his contact lenses prior to examination. The left eyelids were edematous, and there was injection in the left conjunctiva. He had a visual acuity of 20/20 in both eyes. Biomicroscopic examination of the right eye was normal. Examination of left eye revealed several highly motile organisms about $1 \mathrm{~mm}$ long moving on the surface of the conjunctiva (Figure 1). These organisms displayed negative phototaxis moving away from the slit-lamp beam to the fornix. In order to remove them, they were immobilized using $0.5 \%$ propacain drops. Using forceps under slit-lamp examination, approximately 30 specimens of these organisms were removed and placed into a tube for further investigation. The remaining organisms were removed with a moistened cotton bud, and the eye was irrigated with $200 \mathrm{cc}$ saline solution, and the patient recovered quickly from his symptoms. He was prescribed tobramycin eyedrops four times a day and warned not to wear contact lenses during treatment.

The microscopic examination of the organisms showed that they were oval-shaped with segmented bodies and had a pair of large dark oral hooks connected to their cephalopharyngeal skeletons (4). According to these, the organisms were identified as the first instars of Oestrus ovis larvae (Figure 2).

During follow-up examination 1 and 7 days later, no anterior or posterior segment pathology could be observed.

\section{DISCUSSION}

Being an incidental host, humans are rarely infested with myiasis. Most reported cases of myiasis in patients belong to people from tropical countries and from low socioeconomic classes.

Ocular myiasis is generally presented with its external form. Symptoms are that of foreign body discomfort. Punctuate keratitis may be present as a result of the larvae moving across the cornea, and small conjunctival hemorrhages may be present as a result of clinging with the larvae's mouth claws (5). Complications due to ophthalmomyasis may vary from acute conjunctivitis to loss of complete vision.

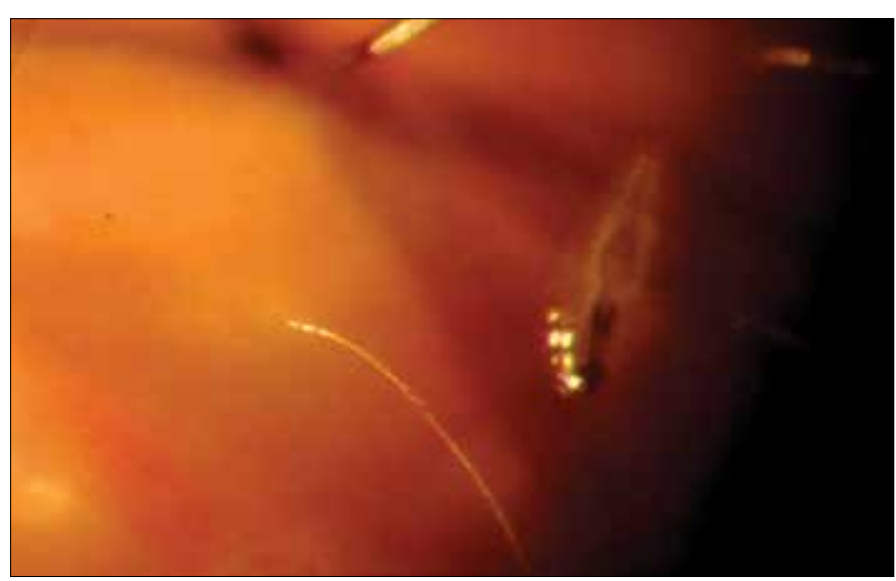

Figure 1. Larva of Oestrus ovis is observed under upper eyelid

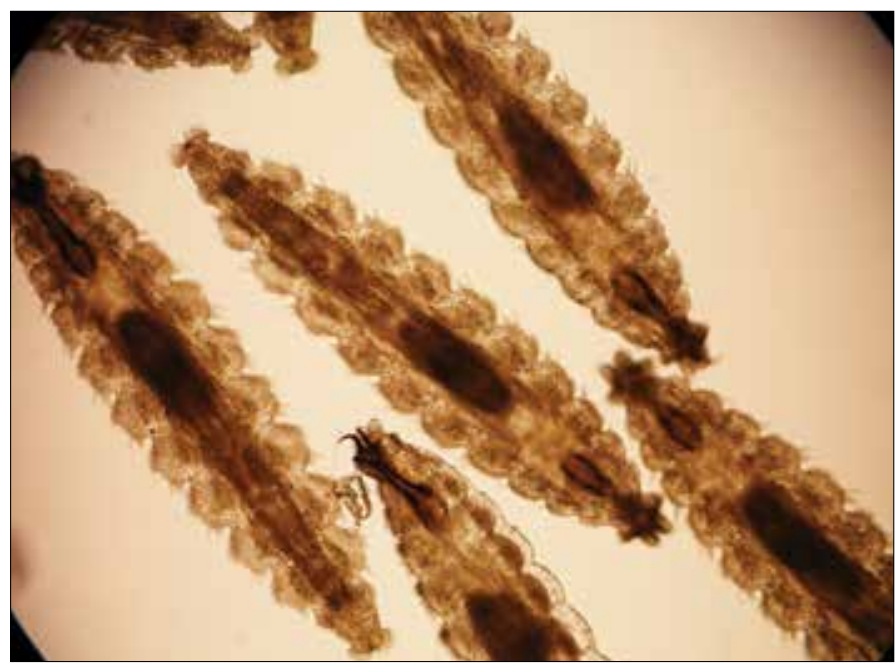

Figure 2. First instars of Oestrus ovis larva about $1 \mathrm{~mm}$ long.Dark oral hooks are seen in the mouth region, which are used for locomotion.

Although cases with ocular myiasis are reported from rural areas, it is interesting that recently, two cases and our case are reported from urban areas $(6,7)$. This may be because diagnosed cases are not reported in the literature.

Manal et al. reviewed 21 cases with ophthalmomyiasis and observed red eye in all cases and reported that $57 \%$ of cases were from rural areas (8).

Ocular parasitic infestations should be kept in mind in patients not only from rural but also from urban areas presenting with viral or allergic conjunctivitis or following a history of something entering the eye. Ophthalmologists should be aware that on routine examination, small and translucent larvae run away from the slit-lamp beam, showing negative phototaxis, thus leading to misdiagnosis of the condition.

\section{CONCLUSION}

Concluding from the cases mentioned above and discussions, ocular parasitic infestations should be kept in mind in patients not only from rural but also from urban areas presenting with 
viral or allergic conjunctivitis or following a history of something entering the eye. Ophthalmologists should be aware that on routine examination, small and translucent larvae run away from the slit-lamp beam, showing negative phototaxis, thus leading to misdiagnosis of the condition.

Informed Consent: Written informed consent was obtained from patients who participated in this case.

Peer-review: Externally peer-reviewed.

Author Contributions: Concept - A.A.; Design - N.S.; Supervision - A.A.; Materials - Z.A.; Data Collection and/or Processing - N.S.; Analysis and/or Interpretation - F.S.; Literature Review - Z.A.; Writing - N.S.; Critical Review - A.A.; Other - Z.A.

Conflict of Interest: No conflict of interest was declared by the authors.

Financial Disclosure: The authors declared that this case has received no financial support.

Hasta Onamı: Yazılı hasta onamı bu olguya katılan hastalardan alınmıştır.

Hakem değerlendirmesi: Dış bağımsız.

Yazar Katkıları: Fikir - A.A.; Tasarım - N.S.; Denetleme - A.A.; Malzemeler - Z.A.; Veri Toplanması ve/veya İşlemesi - N.S.; Analiz ve/veya Yorum - F.S.; Literatür Taraması - Z.A.; Yazıyı Yazan - N.S.; Eleştirel İnceleme - A.A.; Diğer - Z.A.

Çıkar Çatışması: Yazarlar çıkar çatışması bildirmemişlerdir.

Finansal Destek: Yazarlar bu olgu için finansal destek almadıklarını beyan etmişlerdir.

\section{REFERENCES}

1. Gregory A, Schatz S, Laubach $H$. Ophthalmomyiaisis caused by the sheep bot fly Oestrus ovis in northern Iraq. Optom Vis Sci 2004; 81: 586-90. [CrossRef]

2. Bosniak SL, Schiller JD. Ophthalmomyiasis in an eyelid reconstruction. Am J Ophthalmol 1990; 109: 101-2. [CrossRef]

3. Dinçer Ş: Insan ve hayvanlarda miyazis. In Özcel MA, Daldal N.ed. Parazitolojide Artropod Hastalıkları ve Vektörler. Türkiye Parazitoloji Yayınları,No 13, İzmir, 1997; 13: 169-204.

4. Unat EK, Yücel A, Atlaş K, Samastı M, Unat'ın Tıp Parazitolojisi. 5. baskı. İstanbul: Cerrahpaşa Tıp Fak. Yayını 1995. No:15, s. 149-57.

5. Cameron JA, Shoukrey NM, al-Garni AA. Conjunctival ophthalmomyiasis caused by sheep nasal botfly (Oestrus ovis). Am J Ophthalmol 1991; 112: 331-4. [CrossRef]

6. Arslan F, Mete B, Oztürk R, Samasti M. External ophthalmomyiasis caused by Oestrus ovis in İstanbul. Trop Doct 2010; 40: 186-7. [CrossRef]

7. Kuk S, Yildirim S, Ozden M, Erensoy A, Saki CE. Ophthalmomyiasis is not only a problem for rural regions of Eastern Anatolia of Turkey. Med Sci Monit 2009; 15: 166-8.

8. Abdellatif MZ, Elmazar HM, Essa AB. Oestrus ovis as a cause of red eye in Aljabal Algharbi, Libya. Middle East Afr J Ophthalmol 2011; 18: 305-8. [CrossRef] 